\title{
The Empirical Effects of Islam on Economic Development in Malaysia
}

\author{
Wan Ahmad Wan Omar ${ }^{1}$, Fauzi Hussin² \& Asan Ali G H ${ }^{1}$ \\ ${ }^{1}$ College of Business, Universiti Utara Malaysia, Kedah, Malaysia \\ ${ }^{2}$ School of Education and Modern Languages, Universiti Utara Malaysia, Kedah, Malaysia \\ Correspondence: Wan Ahmad Wan Omar, No.7 Jalan Nuri 7/7A, Kota Damansara, 47810 Petaling Jaya, Selangor, \\ Malaysia. Tel: 60-12-376-8692. E-mail: wawo53@gmail.com \\ Received: November 30, 2014 \\ doi:10.5430/rwe.v6n1p99 \\ Accepted: December 23, 2014 \\ Online Published: January 6, 2015 \\ URL: http://dx.doi.org/10.5430/rwe.v6n1p99
}

\begin{abstract}
The studies on the effects of religion on economic development and growth had intrigued the economists to further develop quantitative plausible hypotheses for empirical testing. In Malaysia, albeit implementation of Islamic based policy in economic development had been started since 1969 with the inception of the Pilgrimage Management and Fund Board (Tabung Haji), and recently with the development of Islamic banking and takaful sector; there was very little evidence on the effectiveness of such policy that had been reported by the researchers over the last 40 years. This study was to fill the gap and to review the previous research findings on relationship between Islam and economic development. The objective was to investigate the empirical effects of Islam on economic development in Malaysia. The subject of Islam and economic development had raised a hypothesis whether there was a level relationship in short and long-run equilibria. The Islamization index was employed as a proxy of Islam. Real per capita GDP is used as the indicator of economic development. An autoregressive distributed lag (ARDL) approach was utilized for empirical analyses based on 42-year dataset from 1969 to 2011 . Basically, the results from the cointegration analyses using ARDL approach suggested that Islam, as a religion of the population, had a significant effect on economic development in Malaysia.
\end{abstract}

Keywords: Islam, economic development, Autoregressive Distributed Lag (ARDL), Malaysia

\section{Introduction}

Studies on the relationship between religion and economic development and growth in empirical economic perspective have been conducted by various researchers such as Barro \& McCleary (2003), Mangaloja (2003), Noland (2003) and others who utilize religious activities and beliefs on ordinal scales from World Values Survey results as proxy for religion in their studies. Although significant results were reported, but the relationship was not robust due to heterogeneity in data scale usage where ordinal scale religious proxy is being regressed against time series panel data of economic development indicator and its controlled variables for factors of development. In Islamic economic perspective, the role of Islam as a religious sector in the economy on the economic development has been discussed by Kurshid Ahmad (1978), Umer Chapra (1992), Saleem Qureshi (1980), Mannan (1989) and others. Recent trend among the Muslim scholars in economic development has called for empirical approach in the research on the relationship between Islam and economic development for implementing and monitoring the application of Islamic based policies in the economic development (Umer Chapra, 2000). The economic success of Malaysia with the incorporation of religion and moral values as a basis of economic development over the last forty years provides an opportunity to investigate the relation between religion of Islam and economic development.

The relationship between Islam and economic development in Malaysia has been discussed by many researchers, but restricted to exploratory studies as reported by Aslam Haneef (2001), Wilson (1998), Ataul Huq (2002), and others. Nevertheless, there are several reports on the evidence of positive impact of Islamic banking sector development on economic growth in Malaysia (see Furqani \& Mulyany (2009); Turkan Ali et al., (2012); and Ahmed El-Galfy (2012)). The trend of Islamic based policies adoption in Malaysia since then is rising with the implementation of Islamic banking and takaful services; establishment of Islamic universities, shari'ah compliant funds and unit trusts, halal compliant counters in Bursa Malaysia (Malaysian Stock Exchange), halal hub for products manufacturing and trading; and adoption of Islamic values in the government administration (inculcating Islamic values policy). Unfortunately, the performance of Islamic based policies on economic performance is not specifically reported by 
economists and the government except the performance of Islamic banking and takaful sector which is reported by Malaysian central bank (Bank Negara) in its annual report.

Religion is a highly complex phenomenon because it covers a variety of meanings and being multidimensional in construct, cultural, organizational, individual, and behavioural. The study of religion can be conducted from a variety of disciplines but surveys often seek to capture the religious adherence or religious affiliation and level of religious commitment, or 'religiosity'. The notion of religiosity is mainly connected with terms describing the strength of individual preferences, emotions, beliefs, and actions that refer to the existing professed religion. The subject of religion has also been studied in details by Islamic scholars and they have come to the conclusion that religion is the belief in a "divine being which is worthy of worship and obedience". This definition is from the psychological perspective, in terms of religion, regardless of whether it is considered to be true or false or based on revelation or polytheism (Al-Qaradawi, 2010). This embracing definition is in line with the Qur'anic definition of religion, as in the following verses: "Unto you your religion and unto me my religion" (Qur'an 109:6); and "Those who so seeketh as religion other than Islam will not be accepted from Him, and he will be a loser in the Hereafter" (Qur'an 3:85). Therefore, religion from Islamic perspective is an absolute submission to Allah's will.

The word Islam takes a number of different meanings in the Qur'an. In some verses (ayat), the quality of Islam as an internal conviction is stressed, for example: "Whomsoever God desires to guide, He expands his breast to Islam" (Qur'an 6:125). Other verses establish the connection between Islam and ad-din (usually translated as "religion"), and assert that only the surrender of one's self to Allah can render unto Him the worship which is His due: "Today, I have perfected your religion (ad-din) for you; I have completed My blessing upon you; I have approved Islam for your religion" (Qur'an 5:3). The final category of verses describe Islam as an action (of returning to God), more than simply a verbal affirmation (Qur'an 9:74 and 49:14). The Holy Qur'an claims that all the problems of human life that relates directly or indirectly to the fulfilment of human destiny, in the earthly environment as well as in the hereafter, has been dealt with therein explicitly or implicitly: “... And We reveal the Scripture unto thee as an exposition of all things, and a guidance and mercy and good tidings for those who have surrendered (to Allah) (Qur'an 16:89)".

The notion of 'ad-din', which is literally to mean 'religion', is not the same as the concept 'religion' as interpreted and understood by the Western religious scholars. In Islam, the basic intrinsic inferences in the term 'ad-din' is originated from its main source of the Holy Qur'an and also its origin from Arabic language. The word 'ad-din' is derived from Arabic, 'dyn' has many primary significant which is conceptually interconnected though it seems to have contrary meanings. The primary significant of 'ad-din' could be compressed to four: (1) indebtness; (2) submissiveness; (3) judicious power; and (4) natural inclination or tendency. 'Indebtness' is the meaning of verb 'dana' which derives from ' $a d$-din'. If one finds oneself being in debt, it follows that one subjects oneself, in the sense of yielding and obeying, to law and ordinances governing the debts, and also in a way to the creditor, who is likewise designated as 'da'in'. The meaning of 'ad-din' or 'dana' has various applications in the civilized life, societal law and order, justice and authority. It is, conceptually at least, connected intimately with another word 'maddana' which means to build or create cities: to civilize, to refine and to humanize; from which derived another term: 'tamaddun', meaning 'civilization, and refinement in social culture (Naquib al-Attas, 2001, pp. 41-90). Hence, the concept of civilization and development is embedded in the implication of Islam.

Development is basically a multi-dimensional and comprehensive concept which includes both economic and non-economic factors. The concept of development in economic perspective is defined as economic development which can create economic wealth for better standards of living to the nation's population. From multi-dimensional perspectives, economic development is the result of a combination of social, cultural, political and economic changes inter-alia in capital accumulation, improvement in production techniques, improvement in the economic qualities and productive capacity of labour, heightened spirit of enterprise, etc. The non-economic perspective of development concerns with the social well-being of the population may be indicated by literacy rate, fertility rate, life expectancy, urbanization etc. One of the main factors of development from a non-economic perspective is culture, of which religion is one of the elements (Fukuyama, 2001). Several factors contribute to the process of economic development. Major factors of economic development include consumption, investment and technical progress, trade openness, government administration and economic development planning (Cairncross, 1962). The other important factors include education, culture and religion, investment and technical progress resulting from capital accumulation. The basic control and environment variables for investigating economic development in neoclassical framework are consumption share in the GDP, investment share in the GDP, government share in the GDP, population growth, and trade openness (Barro \& Sala-i-Martin, 2004). 
Empirical researches in economics for time series basically focus on economic analysis of long-run relationship between variables. If the variables in the long-run relation of interest are trend stationary, the general practice is to de-trend the series and remodel the de-trended series as stationary distributed lag or autoregressive distributed lag (ARDL) models. The application of ARDL approach for investigating the existence of a long-run relationship is based on the following assumptions that: (1) Both dependent (endogenous) and independent (exogenous) variables can be introduced into the model with lags, meaning that past values of a variable are allowed to determine its current value; (2) The effect of the exogenous variables on the endogenous may or may not be immediate, depending on the theoretical considerations, therefore, a change in the economic variables may or may not necessarily lead to an immediate change in other variable; and (3) The reaction to a change in each variable may be different depending on various factors, hence there is no reason to assume that all regressors should have the same lags. Estimation and inference with regard to the long-run properties of the models are then conducted based on standard asymptotic normal theory. The analysis, however becomes more complicated when the variables are difference-stationary, or integrated of order 1 (I(1) for short). In the presence of difference-stationary variables and its basic premise or implicitly integrated of order $0(\mathrm{I}(0))$ and integrated of order 1 (I(1) variables in the model, the traditional ARDL approach is no longer applicable. Nevertheless, Pesaran, et al., (2001) have showed that in the presence of difference-stationary variables in the model, the traditional ARDL approach could still be employed with some augmentation. The ARDL specification needs to be augmented first with an adequate number of lagged changes in the regressors prior to conducting estimation and inference on the model, so that the difference-stationary variables become trend-stationary ones in a process known as de-trending. One of the main advantage in the augmented ARDL approach is that the model is capable to analyze level relationship between variables at both short-run and long-run.

The purpose of this paper is to establish empirical evidence on the existence of the long-run relationship between Islam and economic development in Malaysia. Islamization index as discussed by Wan Omar, Fauzi Hussin \& Asan Ali, (2014) is employed as a proxy of Islam. The selection of economic development indicator, per capita GDP and controlled variables for factor of economic development are based on the works of several neoclassical economists (Lucas, 1988; Barro \& McCleary, 2003; and Barro \& Sala-i-Martin, 2004). The controlled variables in the model comprise of consumption share in GDP, investment share in GDP, government expenditure share in GDP and trade openness and religious group ratio to total population (Romer, 1986; Barro \& McCleary, 2003; and Grier, 1997).

There are two research hypotheses: general level relation and development promoting hypothesis (Table 1). In general level relation, the hypothesis is to test the existence of level relation between economic development, indicated by per capita GDP with Islam, proxied by Islamization index and controlled variables which are considered the best factors of economic development. The second hypothesis is to test the effect Islam proxied by Islamization index on economic development indicator, per capita GDP.

Table 1. Research hypotheses

\begin{tabular}{ll}
\hline H & Research Hypotheses \\
\hline $\mathrm{H}-1$ & $\begin{array}{l}\text { General level relation } \\
\text { There is a general level relation between Islam proxied by Islamization index with per } \\
\text { capita GDP and controlled variables. }\end{array}$ \\
\hline $\mathrm{H}-2$ & $\begin{array}{l}\text { Development promoting hypothesis } \\
\text { Islam is posited to contribute positively on economic development. }\end{array}$ \\
\hline
\end{tabular}

The paper is structured into four sections. The first section discusses the introduction including literature review on the existing researches on the subject matter. Second section details out the model, data and application of autoregressive distributed lag (ARDL) approach to analyse the model. Third section illustrates the results on unit root tests, bounds testing and hypothesis results, and followed by discussion on its implications. The final section concludes the study.

\section{Methodology and Data}

\subsection{The Model}

This study employs aggregate production function (APF) in the neoclassical framework, as it is commonly being used by the existing researchers, to estimate the impact of religion on economic growth and development (Azzi \& Ehrenberg, 1975; Grier, 1997; Iannaccone, 1997; and Barro \& McCleary, 2003). The APF assumes that, along with "conventional inputs" of labour and capital used in neoclassical production function, "unconventional inputs" like 
Islam may be included in the model to capture its contribution to economic growth and development. The basic Cobb-Douglas (C-D) form of APF to be estimated is as follows:

$$
Y_{t}=A_{t} K_{t}^{\alpha} H_{t}^{\beta}
$$

where $Y_{t}$ denotes the aggregate production function of the economy (real GDP per capita, indicator of economic development) at time $t$ and $A_{t} . K_{t}, H_{t}$ are the total factor of productivity (TFP), the capital stock and the stock of human capital (population growth) respectively. Following Barro \& McCleary (2003), we assume that capital stock is the function of consumption share in the real per capita GDP, $C_{t}$; investment share in the real per capita GDP, $I_{t}$; government expenditure share in the real per capita GDP, $G_{t}$; and trade openness, $O_{t}$.

$$
K_{t}=f\left(C_{t}, I_{t}, G_{t}, O_{t}\right)
$$

We may replace $H_{t}$ with Muslim population ratio to total population $\left(M_{t}\right)$ and to be considered as "unconventional inputs" as well. Religion from Islamic perspective is more than a belief system as perceived by the secular economists, but a way of life for the Muslims to adhere to. Therefore, we hypothesize that the impact of Islam is probably through TFP as a transmission channel on economic growth and development. Any advantages resulting thereof from the contribution of Islam on TFP will surely be dependent on the implementation of Islamic based institutions and policies in the economic planning in the Muslim country. We can now assume that TFP is the function of Islam and Muslim population ratio to total population, M and other factors, $\left(a_{t}\right)$.

$$
A_{t}=f\left(a_{t}, M_{t},(\text { Islam })_{t}\right)=a_{t} M_{t}^{\beta}(\text { Islam })_{t}^{\gamma}
$$

Replacing $A_{t}$ in equation (3) and $K_{t}$ in equation (2) into equation (1), we get a new extended APF model:

$$
Y_{t}=a_{t} C_{t}^{\alpha_{1}} I_{t}^{\alpha_{2}} G_{t}^{\alpha_{3}} O_{t}^{\alpha_{4}} M_{t}^{\beta}(\text { Islam })_{t}^{\gamma}
$$

Taking natural $\log (\mathrm{L})$ of both sides in equation (4), we can specify the explicit estimable function for Islam and economic development relationship as follows:

$$
\mathrm{L} Y_{t}=c_{0}+\alpha_{1} \mathrm{~L} C_{t}+\alpha_{2} \mathrm{~L} I_{t}+\alpha_{3} \mathrm{~L} G_{t}+\alpha_{4} \mathrm{~L} O_{t}+\beta \mathrm{L} M_{t}+\gamma \mathrm{LIslam}_{t}+\varepsilon_{t}
$$

where $\alpha, \beta, \gamma$ are constant elasticity coefficients of economic development output with respect to the exogenous variables $C_{t}, I_{t}, G_{t}, O_{t}, M_{t}$ and Islam $_{t}$ respectively. $c_{0}$ is a constant parameter and $\varepsilon_{t}$ is the error term. The long-run equilibrium relationship between Islam and economic development are represented in equations (5), which may also constitute a cointegration set.

Based on ARDL model specification as discussed by Pesaran et al., (2001, p. 7), we can now synthesize the basic estimable cointegration model in equation (5) into a conditional vector error correction model (VECM) for the economic growth (per capita GDP), $Y_{t}$ that will be utilized to test hypothesis $\mathrm{H}-1$, and the result is,

$$
\begin{aligned}
\Delta \mathrm{L} Y_{t}=\mathrm{c}_{0} & +\mathrm{c}_{1} t+\delta_{1} \mathrm{~L} Y_{t-1}+\delta_{2} \mathrm{~L} C_{t-1}+\delta_{3} \mathrm{~L} I_{t-1}+\delta_{4} \mathrm{~L} G_{t-1}+\delta_{5} \mathrm{~L} O_{t-1}+\delta_{6} \mathrm{~L} M_{t-1}+\delta_{7} \mathrm{~L} \text { Islam }_{t-1} \\
& +\sum_{i=1}^{p} \epsilon_{i} \Delta \mathrm{L} Y_{t-i}+\sum_{j=1}^{q} \theta_{1 j} \Delta \mathrm{L} C_{t-j}+\sum_{j=1}^{q} \theta_{2 j} \Delta \mathrm{L} I_{t-j}+\sum_{j=1}^{q} \theta_{3 j} \Delta \mathrm{L} G_{t-j}+\sum_{j=1}^{q} \theta_{4 j} \Delta \mathrm{L} O_{t-j} \\
& +\sum_{k=1}^{q} \vartheta_{k} \Delta \mathrm{L} M_{t-k}+\sum_{l=1}^{q} \mu_{l} \Delta \mathrm{L} \text { Islam }_{t-l}+\varepsilon_{t} \\
& t=1,2,3, \ldots, T
\end{aligned}
$$

where $\delta_{i}$ are long-run multipliers, $\mathrm{c}_{0}$ is the intercept or drift, $\mathrm{c}_{1} t$ is deterministic time trend, and $\varepsilon_{t}$ are white noise errors. VECM in equation (6) is the specifications for hypotheses testing for level relations between each variable of economic development indicator and Islamization index (H-1) using bounds testing procedure advanced in Pesaran et al., (2001). The main advantage of this testing and estimation strategy lies in the fact that it can be applied irrespective of whether the regressors are I(0) or I(1), and can avoid the pre-testing problems associated with the standard cointegration analysis which requires the classification of the variables into $\mathrm{I}(1)$ and $\mathrm{I}(0)$. The null hypothesis of non-existence of the long-run relationship is to test the coefficients of lagged variables, $\delta_{i}$,

$$
H_{0}: \quad \delta_{1}=\delta_{2}=\delta_{3}=\delta_{4}=\delta_{5}=\delta_{6}=\delta_{6}=0
$$

against

$$
H_{1}: \quad \delta_{1} \neq 0, \quad \delta_{2} \neq 0, \quad \delta_{3} \neq 0, \quad \delta_{4} \neq 0, \quad \delta_{5} \neq 0, \quad \delta_{6} \neq 0, \quad \delta_{7} \neq 0
$$


The first step in bounds testing procedure, we use ordinary least square (OLS) method for estimation the ARDL models based on selected deterministic properties (with intercept and time trend). Joint significant of the long-run coefficients $\left(\delta_{1}\right.$ to $\delta_{7}$ for equations 6$)$ using familiar F-statistic is then applied for testing the significance of the lagged level of the variables in the error correction (ECM) form of the underlying ARDL model. If the computed F-statistic is higher than upper bounds critical value (which has been tabulated in Appendix-B, Pesaran \& Pesaran (2009)) then we shall reject the null hypothesis of no long-run relation between Islam, economic development and its factors.

We employ last three steps of bounds testing procedure to test for development promoting hypothesis (H-2) based on ARDL specification in equation 6 . In the second step, the optimum number of lags length and selecting the order of $\operatorname{ARDL}\left(p_{1}, q_{1}, \ldots, q_{i}\right)$ model are estimated by AIC or SBC selection criteria. Long-run coefficients of the $\operatorname{ARDL}\left(p_{1}, q_{1}, \ldots, q_{i}\right)$ model is then estimated for significance check. The hypothesis test is conducted Wald or F-statistic for level relationship and probability ratio of t-statistic for significance of the long-run and short-run coefficients of the regressors. In the third and final step we obtain the short-run dynamic parameters by estimating an error correction model associated with the long-run estimates for Islamization index based on reduced ARDL specifications for per capita GDP, $Y_{t}$ in equation (7). The hypothesis is positive if their regressors' coefficients are significant at more than $90 \%$ confidence level.

$$
\begin{gathered}
\Delta \mathrm{L} Y_{t}=\rho+\sum_{i=1}^{p} \epsilon_{i} \Delta \mathrm{L} Y_{t-i}+\sum_{j=1}^{q} \theta_{1 j} \Delta \mathrm{L} C_{t-j}+\sum_{j=1}^{q} \theta_{2 j} \Delta \mathrm{L} I_{t-j}+\sum_{j=1}^{q} \theta_{3 j} \Delta \mathrm{L} G_{t-j}+\sum_{j=1}^{q} \theta_{4 j} \Delta \mathrm{L} O_{t-j}+\sum_{k=1}^{q} \vartheta_{k} \Delta \mathrm{L} M_{t-k} \\
+\sum_{l=1}^{q} \mu_{l} \Delta \mathrm{L} \text { Islam }_{t-l}+\tau e c m_{t-1}+\varepsilon_{t} \\
t=1,2,3, \ldots, T
\end{gathered}
$$

\subsection{Data}

We employ the Islamization index in Wan Omar et al., (2014) as proxy for religion of Islam based on time series dataset from 1969 to 2011 (base year, $1969=100$ ). Details on other data collection sources for indicators and factors of economic development are presented in Table 2.

Table 2. Sources for data collection

\begin{tabular}{lll}
\hline Description & Variables & Sources of Data \\
\hline $\begin{array}{l}\text { Indicator of } \\
\text { Economic } \\
\text { Development }\end{array}$ & $\begin{array}{l}\text { Real GDP per capita (in constant 2005 price } \\
\text { in US\$) }\end{array}$ & $\begin{array}{l}\text { Summer, Heston \& Aten } \\
\text { (Penn World Table 7.1). } \\
\text { Barro dataset. }\end{array}$ \\
\hline Factors of Economic & Muslim Population Ratio to Total & Malaysia Dept. of Statistics. \\
Development & $\begin{array}{l}\text { Population } \\
\text { Share of Consumption to real GDP }\end{array}$ & $\begin{array}{l}\text { Pew Forum on Religion. } \\
\text { Penn World Table 7.1 }\end{array}$ \\
& Share of Govt Expenditure to real GDP & Penn World Table 7.1 \\
& Share of Investment to real GDP & Penn World Table 7.1 \\
& Trade Openness & Penn World Table 7.1 \\
\hline Islam & Islamization Index & Wan Omar et al., (2014)
\end{tabular}

\section{Results}

\subsection{Data Preliminaries}

Figures 1 to 2 depict the time series plots of all data variables in natural log-linear form that are employed in the analysis, comprising real per capita GDP, controlled variables for factors of economic development, Muslim population ratio and Islamization index. The level of GDP per capita (Y) in US dollar (in year 2005 constant value) showed an increasing trend throughout the investigation period (1969-2011). Trend of Islamization index in the early sample period (base year index, $1969=100$ ) is basically flat and very thin until introduction of Islamic banking and financial system that took place in the 1980's. From 1990 onwards, the index has experienced exponential growth, in which Islamic capital market was a major contributor. 

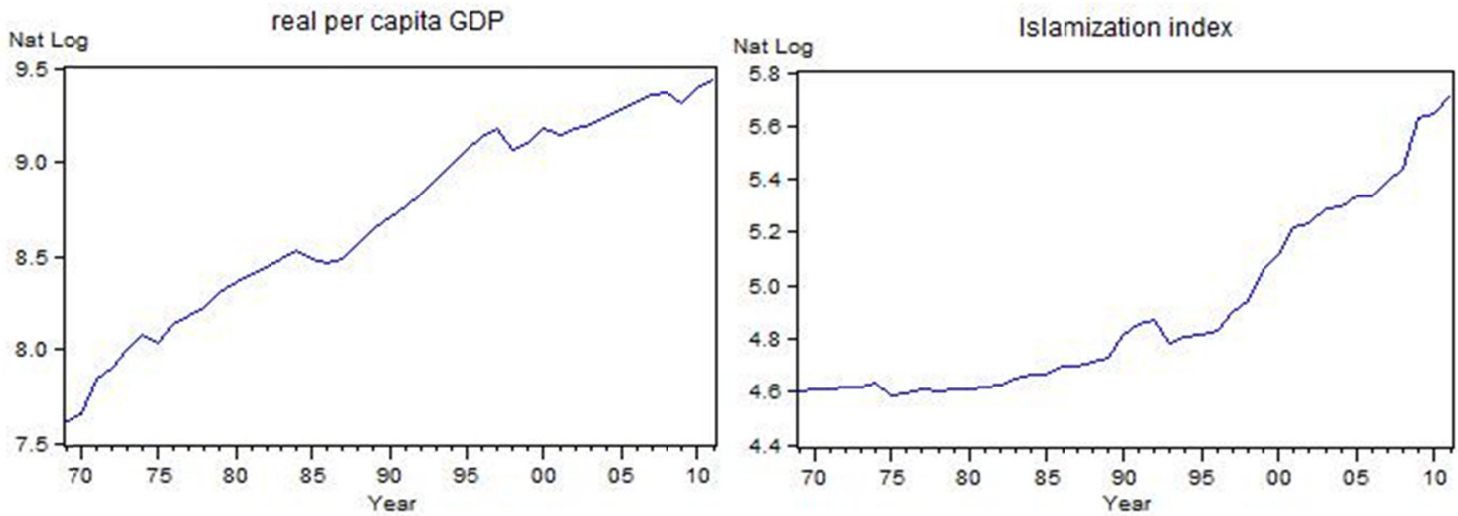

Figure 1. The trends of real per capita GDP and Islamization index in Malaysia

Until 1999, the consumption share in GDP line graph had been in steadily decreasing trend (see Figure 2). During the same period, there were erratic increases of investment and government expenditure shares in GDP as well as trade openness. Government expenditure was in declining trend beginning 1982 and bounced back in the year 2000 onwards. The plots for all the variables that are presented in Figure 1 and 2 show the properties of deterministic time trend and intercept in its time series data properties. Therefore, these suggests, at least initially that time trend and intercept option need to be included in the ARDL analysis for unit root and bound tests.

\subsection{Unit Root Tests}
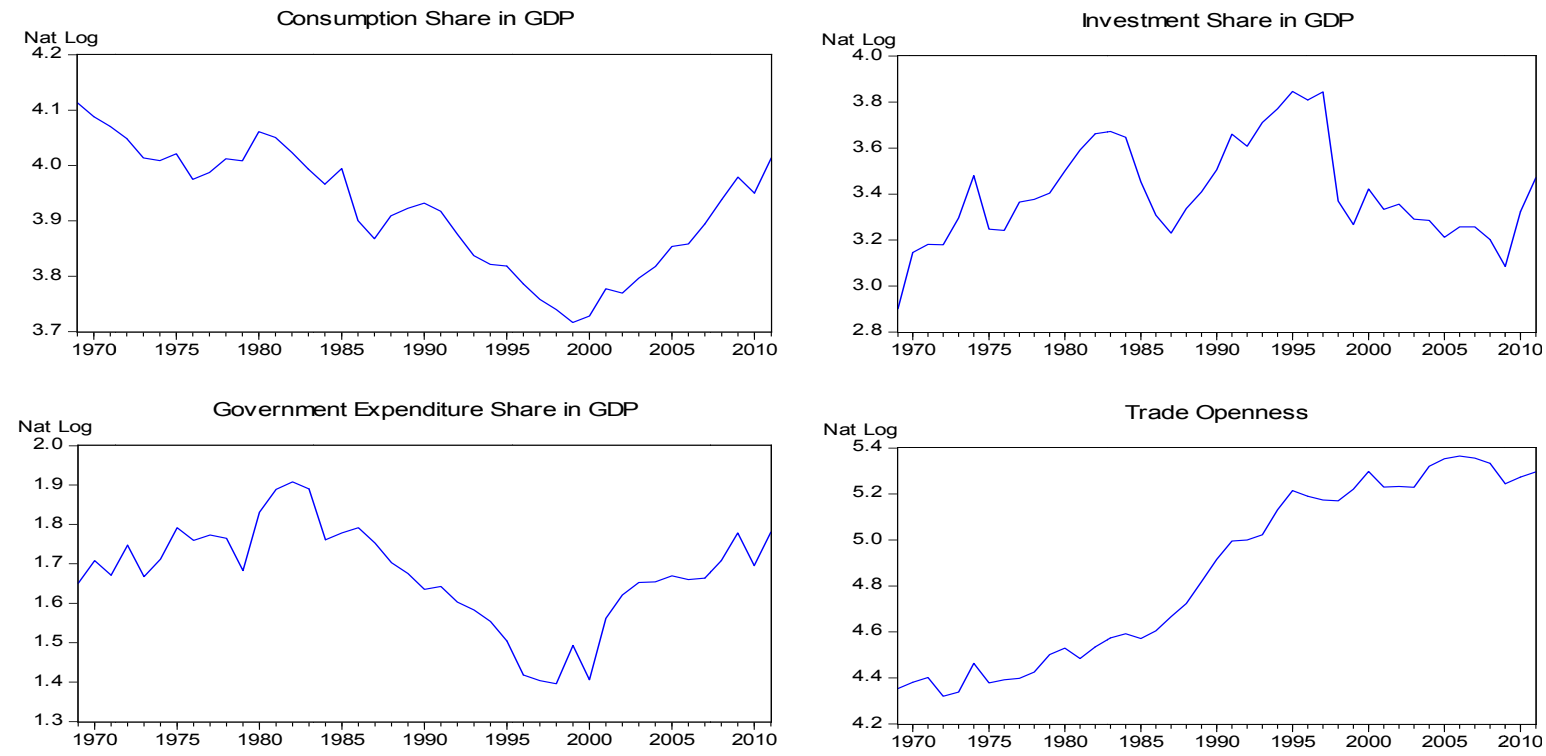

Figure 2. Trends of controlled variables in Malaysia

The purpose of unit root tests is to check the stationarity status of all variables in the model and the order of its integration after differencing. This is to ensure that the variables are not $\mathrm{I}(2)$ or $\mathrm{I}(\mathrm{d})$ stationarity so as to avoid spurious results and ARDL approach could not be applied to the model. The lag length is automatically calculated by the system but pegged to the maximum of 5 , the number of lag assumption that is considered sufficient to remove any serial correlation in the residual. An Akaike information criterion (AIC) for the lag length selection is also adopted. The results of unit root tests (t-statistic) for the 7 variables in the model under deterministic trend and intercept, and intercept only options are presented in Table 3. 
Table 3. Unit root tests using ADF and AIC selection criteria

\begin{tabular}{|c|c|c|c|c|c|c|c|c|}
\hline \multirow{2}{*}{ Var } & \multicolumn{4}{|c|}{ with Trend and Intercept } & \multicolumn{4}{|c|}{ with Intercept only } \\
\hline & Level & $1^{\text {st }}$ Diff & $2^{\text {nd }}$ Diff & $\mathbf{I}(\mathbf{d})$ & Level & $1^{\text {st }}$ Diff & $2^{\text {nd }}$ Diff & $\mathbf{I}(d)$ \\
\hline GDP & -1.432 & $-6.291 * * *$ & & $\mathrm{I}(1)$ & -0.635 & $-6.319 * * *$ & & $\mathrm{I}(1)$ \\
\hline $\mathrm{C}$ & 0.712 & $-6.571 * * *$ & & $\mathrm{I}(1)$ & -1.730 & $-5.985 * * *$ & & $\mathrm{I}(1)$ \\
\hline I & -2.334 & $-7.244 * * *$ & & $\mathrm{I}(1)$ & -2.541 & $-7.215 * * *$ & & $\mathrm{I}(1)$ \\
\hline G & -1.866 & $-7.970 * * *$ & & $\mathrm{I}(1)$ & -1.874 & $-8.051 * * *$ & & $\mathrm{I}(1)$ \\
\hline Open & -1.952 & $-6.457 * * *$ & & $\mathrm{I}(1)$ & 0.289 & $-6.342 * * *$ & & $\mathrm{I}(1)$ \\
\hline M & $-7.296 * * *$ & $-7.875 * * *$ & & $\mathrm{I}(0)$ & $-7.870 * * *$ & $-7.129 * * *$ & & $\mathrm{I}(0)$ \\
\hline Islam & -0.577 & $-4.524 * * *$ & & $\mathrm{I}(1)$ & 2.185 & $-3.033 * *$ & & $\mathrm{I}(1)$ \\
\hline
\end{tabular}

Notes:

$\mathrm{t}$-stat $=\mathrm{t}$ statistics. GDP $=$ Gross Domestic Product per capita. $\mathrm{I}(\mathrm{d})=$ integrated by the order of $d$. $\mathrm{C}=$

Consumption share in GDP. I = Investment share in GDP. G = Government expenditure share in GDP.

Open $=$ Trade openness. $\mathrm{M}=$ Muslims to total population ratio. Islam = Islamization Index.

The null hypothesis is that the time series is non-stationary, or contains a unit root.

$* * *$ Significance at $1 \%$. ${ }^{* *}$ Significance at $5 \%$. $*$ Significance at $10 \%$.

The application of the unit root tests on the variables has produced mixed results, with strong evidence in favour of the unit root hypothesis with less than 5 percent significance level in all of the cases except Muslims to total population ratio variable, which is significant without differencing. All variables in the model comprise a combination of cointegration $\mathrm{I}(0)$ and $\mathrm{I}(1)$, hence complied with the unit roots test requirement to proceed for bounds testing procedure in the autoregressive distributed lag (ARDL) approach (Pesaran \& Pesaran, 2009).

\subsection{Bounds Testing and Hypotheses Result}

The bounds testing procedure involves two stages: the first stage is to test the existence of the long-run relationship between variables under investigation by computing the F-statistic using OLS method for testing the significance of the lagged levels of the variables in the error correction form of the underlying functions based on equation (6). This is also to test research hypotheses for H-1 (general level relation), level relationships between variables in the model. Significance of lagged level is determined by comparing calculated F-statistic with the tabulated critical value. Since the time series data are annual basis, as suggested by Pesaran \& Shin (1999) we choose 2 and 3 as the maximum lag order in the ARDL model specification for estimated period from 1969 to 2009, retaining the remaining two observations (2010 and 2011) for predictions. The F-statistic is calculated for each model under two options - a deterministic trend and intercept included; and an intercept only model. Summary of bound tests result based on F-statistic based on AIC selection at lag 2 and 3 with intercept and time trend properties is illustrated in Table 4.

The result of F-statistic for the ARDL functions $F_{Y}$ with intercept only property is 8.186 as compared to 7.108 for intercept and time trend included, in which both as expected are higher than upper critical value of 3.883 at $1 \%$ significant. This suggests that if time trend is not included into the model, the significant test for the model is better off. Since the result of F-statistic for $F_{Y}$ exceeds the upper bound critical value, we can reject the null of no long run relationship between variables in ARDL model irrespective of the order of their integration, meaning that there is a level relation between Islam proxied by Islamization index with economic development indicator, per capita GDP and controlled variables in the ARDL model specification as per equation (6).

Table 4. Bounds testing for ARDL models based on equation (6)

\begin{tabular}{llcccc}
\hline No. & ARDL Model & $\begin{array}{l}\text { F-Stat } \\
\text { (Int only) }\end{array}$ & $\begin{array}{c}\text { F-Stat } \\
\text { (Int+Trend) }\end{array}$ & $\begin{array}{c}\text { AIC } \\
\text { Lag }\end{array}$ & Outcome \\
\hline 1. & $F_{Y}(Y \mid C, I, G, O, M$, Islam $)$ & $8.186^{* * *}$ & $7.108^{* * *}$ & 3 & Reject $\mathrm{H}_{0}$ \\
2. & $F_{\text {Islam }}($ Islam $\mid Y, C, I, G, O, M)$ & 1.243 & 1.162 & 2 & Do not Reject $\mathrm{H}_{0}$ \\
\hline & Notes: \\
& Y = per capita GDP. I = Investment share in GDP. G = Government share in GDP. O = Trade openness. M = Muslim \\
& population ratio to total population. Islam = Islamization Index. Int = Intercept. \\
& Critical value at 95\% confidence level for Case III: intercept and trend for d.f. or k=7 is given in (Pesaran \& Pesaran, 2009). \\
& Lower bound = 2.752. Upper bound = 3.883. For Case II intercept only: Lower bound 2.365, Upper bound 3.553. \\
& *** 1\% significance level. ** 5\% significance level. * 10\% significance level. \\
\hline
\end{tabular}


To consider the significance of the lagged level variables in the error correction model in equation (6) explaining $D L C_{t}, D L I_{t}, D L G_{t}, D L O_{t}, D L M_{t}, D L I s l a m_{t}$ as long run forcing variables for $D L Y_{t}$, we back-tract the dependent variable in the model as per ARDL functions and test for joint significance using F-statistic. The F-statistic results of ARDL functions for factor of economic development and Islamization index, denoted by $F_{C}(C \mid Y, I, G, O, M$, Islam), $F_{I}(I \mid Y, C, G, O, M$, Islam $), F_{G}(G \mid Y, C, I, O, M$, Islam $), F_{O}(O \mid Y, C, I, G, M$, Islam $), F_{M}(L \mid Y, C, I, G, O$, Islam $)$, and $F_{\text {Islam }}($ Islam $Y, C, I, G, O, M)$ except for consumption as expected are less than lower bound 2.365 , indicating the null hypothesis that the level variables do not enter significantly into the equations for $I, G, O, M$ and Islam cannot be rejected. Hence, the null hypothesis that the level variables $D L C_{t}, D L I_{t}, D L G_{t}, D L O_{t}, D L M_{t}$, and $D L I s l a m_{t}$ do not enter significantly into the ARDL models cannot be rejected. This conclusion, once again holds irrespective of whether the underlying variables are I(0) or I(1). The above result suggests that there exists long-run relationship between economic development (proxied by per capita GDP), its controlled variables and Islamization index in equation (6), and the variables $D L C_{t}, D L I_{t}, D L G_{t}, D L O_{t}, D L M_{t}$ and $D L I s l a m_{t}$ can be treated as the "long-run forcing" variables for the explanation of $D L Y_{t}$. The result also suggests using intercept only equation in the ARDL model for the next stage of bound tests. Hence, we have proved research hypothesis for general level relation $\mathrm{H}-1$ that there is a level relationship between Islam proxied by Islamization index and economic development and its factors (controlled variables) is right.

The second stage in ARDL procedure is to test hypothesis H-2 (development promoting) by estimating the coefficients of the long-run relationships between variables in the model (equation 7) with chosen 3 lags length and intercept only property. We also use AIC selection criterion for the ARDL model. The results of estimated long-run coefficient for the revised ARDL model with lag order of 3 for per capita GDP equation were given in Table 5. The $\operatorname{ARDL}(2,3,1,1,2,3,2)$ model has passed the testing for existence of a level relationship among the variables (F-statistic was 6.1626 which is higher than upper bound of 4.1990 at $5 \%$ significance level), and has also passed all diagnostic tests - serial correlation, functional form, normality and heteroscedasticity, that are automatically computed by the system. The result of long-run coefficients of the regressors in development promoting hypothesis is mixed, where only coefficients for investment and trade openness are highly significant (Table 5). This indicates that economic growth (per capita GDP) in Malaysia is largely driven by investment and international trade, and the role of Islamic sector in development promoting is still at infancy stage.

Table 5. Estimated long-run coefficient using for ARDL model $(\mathrm{p}=3)$

ARDL(2,3,1,1,2,3,2) selected based on Akaike Information Criterion

Dependent variable is $\mathrm{L}(\mathrm{Y})$ - per capita GDP

\begin{tabular}{lrrr}
\hline Regressor & Coefficient & Std Error & T-Ratio[Prob] \\
\hline L (Consumption) & -.19657 & .39342 & $-.49965[.623]$ \\
L (Investment) & .46295 & .15081 & $3.0697[.006]$ \\
L (Govt Exp) & -.20464 & .28383 & $-.72101[.480]$ \\
L (Trade Openness) & .93574 & .40312 & $2.3212[.032]$ \\
L (Muslim Pop) & -2.2659 & 8.3049 & $-.27284[.788]$ \\
L (Islam Index) & .38385 & .26422 & $1.4528[.163]$ \\
INPT (Intercept) & 11.4326 & 31.5954 & $.36184[.721]$ \\
\hline
\end{tabular}

Testing for existence of a level relationship among the variables in the ARDL model

\begin{tabular}{ccccc} 
F-statistic & $95 \%$ Lower B & $95 \%$ Upper B & $90 \%$ Lower B & $90 \%$ Upper B \\
6.1626 & 2.8131 & 4.1990 & 2.3552 & 3.6088 \\
W-statistic & $95 \%$ Lower B & $95 \%$ Upper B & $90 \%$ Lower B & $90 \%$ Upper B \\
43.1384 & 19.6920 & 29.3933 & 16.4862 & 25.2613 \\
\hline
\end{tabular}

If the statistic lies between the bounds, the test is inconclusive. If it is above the upper bound, the null hypothesis of no level effect is rejected. If it is below the lower bound, the null hypothesis of no level effect can't be rejected. The critical value bounds are computed by stochastic simulations using 20000 replications.

Table 6 illustrates the results of short-run dynamic coefficients obtained from error correction model (ECM) that are associated with the above-mentioned long-run relationship. The error correction coefficient is estimated at -0.19067 $(0.083685)$ which is statistically significant at $5 \%$ level, has the correct sign and suggests a moderate speed of convergence to equilibrium given by equation (7). Generally, the regression fits reasonably well ( $\mathrm{R}^{2}$ is 0.96732$)$ and satisfies all the diagnostic tests including serial correlation (DW-statistic is 2.3829), although several insignificant 
coefficient still remained in this error correction specification. These estimates provide further evidence on the dynamics nexus that seem to exist between Islam proxied by Islamization index and economic growth, and the level relationship between economic growth and its main determinants or controlled variables. Barro \& McCleary (2003) have also reported a similar result in their empirical study on relationship between religion and economic growth; that the economic growth responds positively to the extent of religious beliefs, notably those in hell and heaven, but negatively to church attendance. The other consistent results on the study on effect of religion on economic growth were also reported by Mangeloja (2005) and Grier (1997).

Table 6. The log-linear error correction model of per capita GDP equation

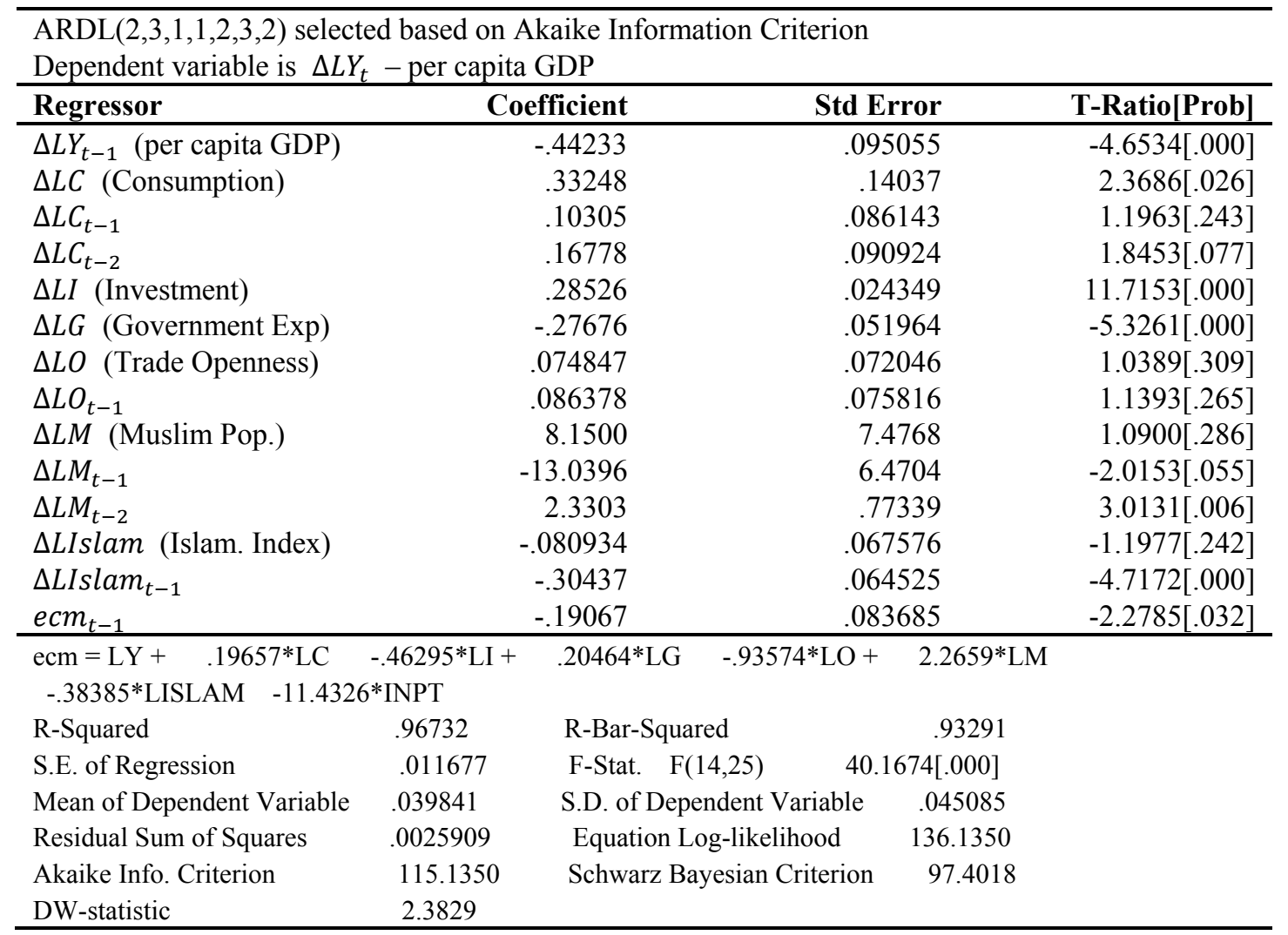

\subsection{Stability Test and Predictive Power}

Plots of cumulative sum of recursive residuals (CUSUM) and cumulative sum of squares (CUSUMSQ) of recursive residuals of the error correction model also suggest that the regression coefficients are generally stable over the sample period and do not show any evidence of statistically significant break (see Figure 3 and 4). However, Pesaran et al. (1999) have noted that these tests are known to have low powers and are likely to have missed some important breaks. The above error correction model has also predictive power in forecasting the rate of change of economic growth conditional on current and past changes in controlled variables and Islamization index based on equation (7).

The results of the dynamic forecasts for the change in log-linear equation of economic growth are depicted in Table 8 . The root mean sum squares of forecast errors of $2.79 \%$ per year compares favourably with the value of the same criterion computed over the estimation period. The model also able to forecast the extent of changes in the economic growth in the years 2010 and 2011 with minimum error as expected. 


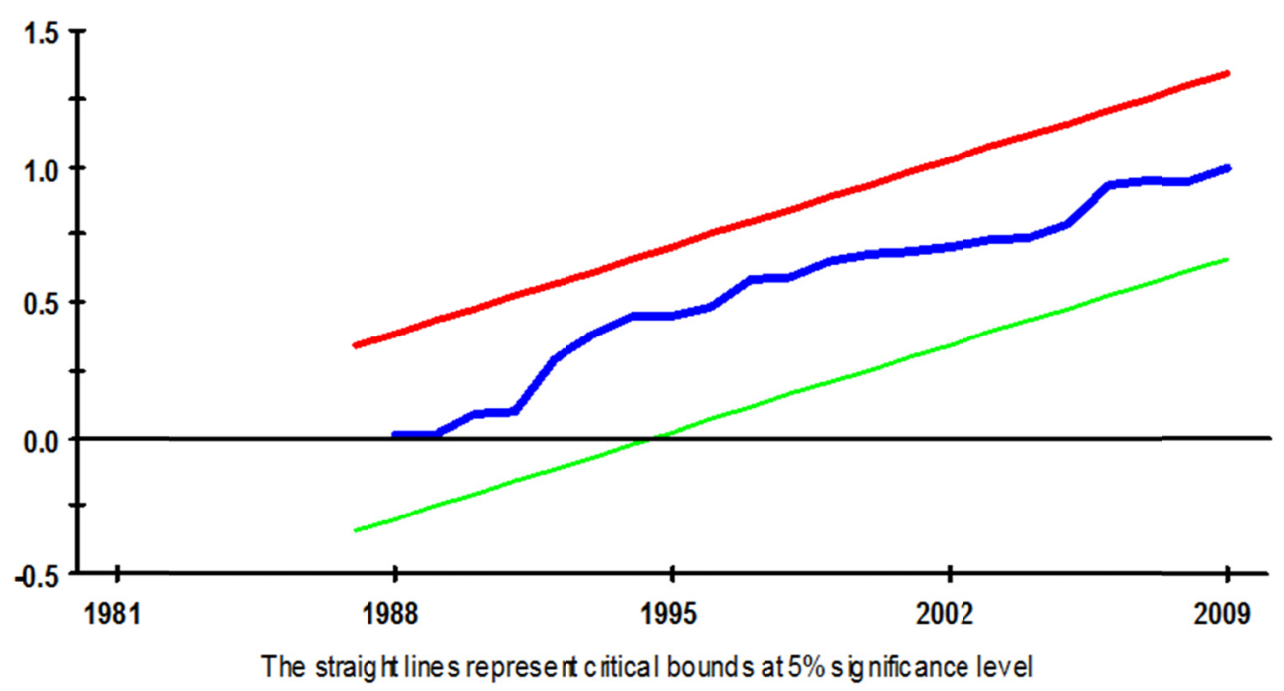

Figure 3. Plot of cumulative sum of recursive residuals of economic development-Islam nexus

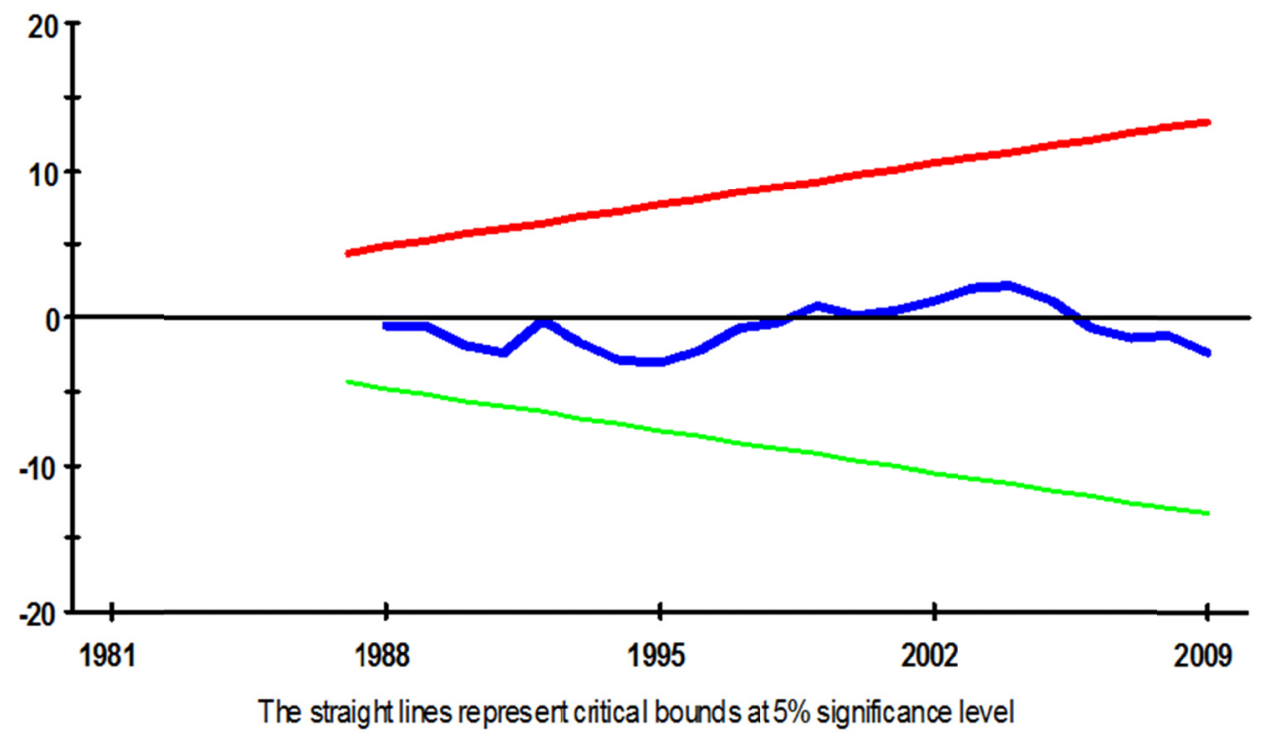

Figure 4. Cumulative sum of squares of recursive residuals for economic development-Islam nexus

The results of the dynamic forecasts for the change in log-linear equation of economic growth are depicted in Table 7. The root mean sum squares of forecast errors of $2.79 \%$ per year compares favourably with the value of the same criterion computed over the estimation period. The model also able to forecast the extent of changes in the economic growth in the years 2010 and 2011 with minimum error as expected. 
Table 7. Dynamic forecasts for change in log-linear economic growth

\section{Forecast Results}

$\operatorname{ARDL}(2,3,1,1,2,3,2)$ selected using Akaike Information Criterion.

Dependent variable in the ARDL model is LY included with a lag of 2.

\begin{tabular}{llll}
\hline Observation & Actual & Prediction & Error \\
\hline 2010 & .069927 & .046718 & .023210 \\
2011 & .049742 & .017880 & .031862 \\
Summary Statistics for Residuals and Forecast & Errors & \\
\hline & Estimation Period & Forecast Period \\
& $\mathbf{1 9 7 2}$ to 2009 & $\mathbf{2 0 1 0}$ to 2011 \\
\hline Mean & $.6730 \mathrm{E}-6$ & .027536 \\
\hline Mean Absolute & .0063793 & .027536 \\
Mean Sum Squares & $.6544 \mathrm{E}-4$ & $.7770 \mathrm{E}-3$ \\
Root Mean Sum Squares & .0080896 & .027874 \\
\hline
\end{tabular}

The plot of dynamic forecast of the model is depicted in the Figure 5 which shows that the forecast values of changes in LY are fitted well with the actual values and with minimum forecast error as computed in Table 7.

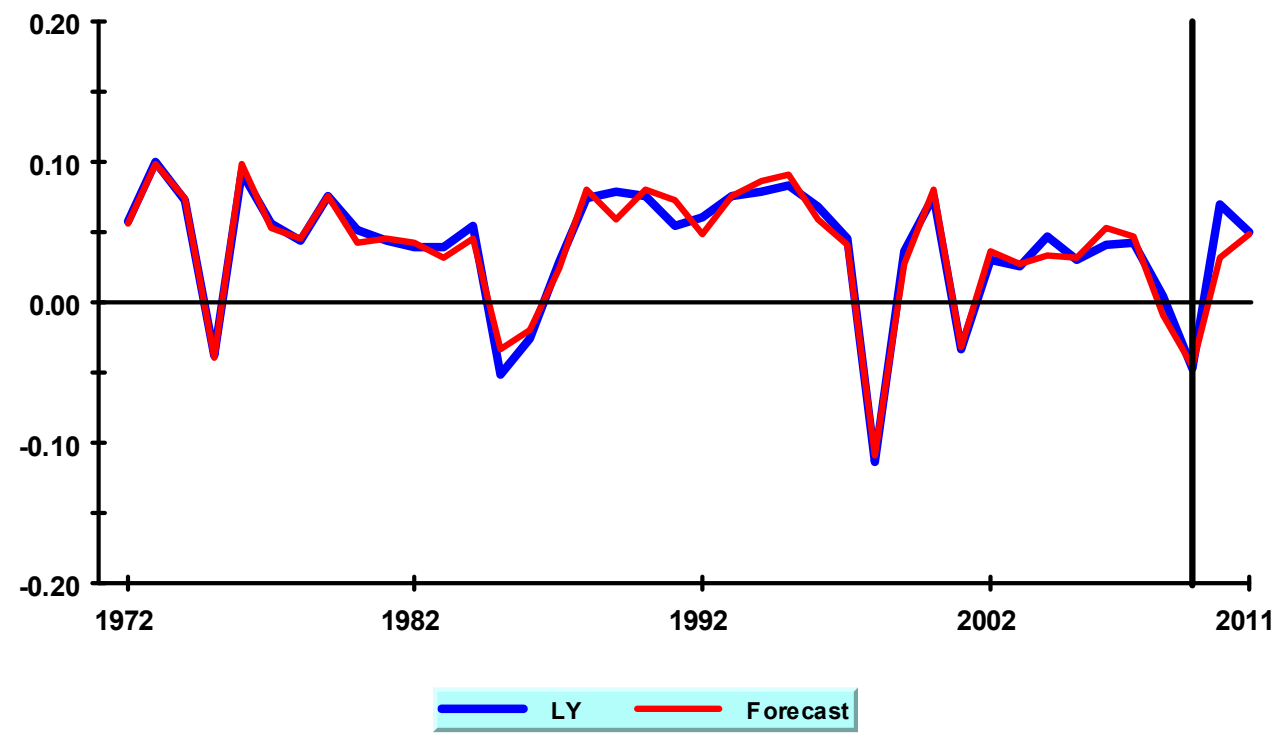

Figure 5. Plot of dynamic forecast vs actual in per capita GDP- Islam equation

\section{Discussion and Implication}

This paper applies the concept of cointegration using ARDL approach to investigate the effects of the religion of Islam on economic development based on time series sample data collected in Malaysia from 1969 to 2011. There has been exponential growth of Islamization process in Malaysia over the last decade largely contributed by the rapid growth of Islamic capital in the economy. In Malaysia, Islam has contributed to the establishment of Islamic financial system as an alternative to the existing conventional financial system. Its formation was the result of Islamic revival in the 1969 and the aspiration of the majority of the population who wanted to have a financial system which was in compliance with shari'ah so that their life would not be sinned with un-Islamic economic activities like riba in the financial services. Total Islamic capital in Malaysia was estimated at RM343.2 billion in 2000, and increased to RM847.3 billion in 2011. The size of Islamic capital as a ratio to GDP has also significantly increased from $24.3 \%$ of GDP in 2000 to $58.7 \%$ of GDP in 2011 at the average growth rate of $8.3 \%$ per year, surpassing the average growth of GDP at 4.4\% per annum during the same period (Wan Omar W. , 2012). Therefore, it is timely to analyze contribution of Islam as an economic policy variable on economic development. 
Basically, the results from cointegration analysis using ARDL approach in this study have suggested that Islam, as a religion of the population, has a significant influence on the development and economic growth in Malaysia. All the selected variables in the model have passed the prerequisite unit root test before proceeding to bounds test for hypotheses testing. The test results for joint null hypothesis from F-statistic and W-statistic of bound tests support the existence of long-run relationship between economic development indicator, per capita GDP with Islam proxied by Islamization index when an appropriate lag length $(\mathrm{p})$ is selected and without imposition of deterministic time trend into the ARDL specification model.

In the second hypothesis (H-2) on development promoting, the result of long-run coefficients of the regressors including Islamization index is mixed, in which Islamization index is not one of the significance regressors. The main reason for this failure in development promoting hypothesis is revealed by data preliminary graph on Islamization index, that the index is basically flat and thin until 1995. The rapid growth of Islamization process in Malaysia is recorded from 2000 onwards or about last decade and half. We believe that Islamization index will pass development promoting hypothesis in a few years time considering the growth of the index presently.

Conversely, the result from error correction model (ECM) for short-run of the ARDL model provides further evidence that there is a dynamic nexus between Islam with economic development and its selected factors in the controlled variables. The error correction coefficient, estimated at -.191 (.08) is statistically significant, has the correct sign and suggests a relatively moderate speed of convergence in the economy to equilibrium once shocked. This result means that approximately $19.1 \%$ of disequilibria from the previous year's shock converge back to the long-run equilibrium in the current year (see Table 6). The error correction model also passed stability test without any statistically significant break (see Figure 3 and 4), and an economic development model that includes Islam has a good predictive power (see Figure 5).

These above-mentioned results implicate that Islam has the potential to be a policy target for prompting long-run economic growth and development.

\section{Conclusion}

The above policy implications and conclusion are evidently drawn from the present study for which the results are merely treated as suggestive empirical regularities. The Islam and economic development regression results from autoregressive distributed lag approach are simply viewed as evaluating the existence of such relationship in short-run or long-run or both. The ARDL results also indicate the existence of behavioural relationship between Islam and economic development indicators that suggest how much the level of the indicators will change when the Islamization index changes. Therefore, the results from this study are very useful in influencing the belief about the relevance and relative significance of Islamic sector development policies for short-run and long-run economic development. What we can learn from this study is that the short-run and long-run estimates from the results may provide a simple barometer to reflect the degree of the actual occurrence in the development of Islamic sector in the economy. Through this study, for instance, there is an indication that Islamic sector development is moving in a favourable direction in supporting economic development.

\section{References}

Ahmed El-Galfy. (2012). Islamic Banking and Economic Growth. The Journal of Applied Business Research, 943-957.

Al-Qaradawi, Y. (2010). Islam: An Introduction. (Translation from Arabic) (New ed.). Kuala Lumpur: Islamic Book Trust.

Aslam Haneef. (2001). Islam and Economic Development in Malaysia - a reappraisal. Journal of Islamic Studies, 12(3), 269-290. http://dx.doi.org/10.1093/jis/12.3.269

Ataul Huq, P. (2002). Islam and Economic Development Revisited with Evidences from Malaysia. Islamic Economic Studies, 10(1).

Azzi, C., \& Ehrenberg, R. G. (1975). Household Allocation of Time and Church Attendence. Journal of Political Economy, 83(1), 27-56. http://dx.doi.org/10.1086/260305

Barro, R. J., \& McCleary, R. (2003). Religion and Economic Growth. National Bureau of Economic Research (NBER) Working Papers Series.

Barro, R. J., \& Sala-i-Martin, X. (2004). Economic Growth (2nd ed.). London: The MIT Press.

Cairncross, A. (1962). Factors in Economic Development. New York: Praeger Publications. 
Fukuyama, F. (2001). Culture and Economic Development. International Encyclopedia of Social and Behavioral Sciences. Amsterdam, Holland: Elsevier Science. http://dx.doi.org/10.1016/BO-08-043076-7/04584-8

Furqani, H., \& Mulyany, R. (2009). Islamic Banking and Economic Growth: Empirical evidence from Malaysia. Journal of Economic Cooperation and Development, 59-74.

Grier, R. (1997). The Effect of Religion on Economic Development: a cross national study of 63 former colonies. KYKLOS, 1, 47-62. http://dx.doi.org/10.1111/1467-6435.00003

Iannaccone, L. R. (1998). Introduction to the Economics of Religion. Journal of Economic Literature, 3, $1465-1495$.

Kurshid Ahmad. (1978). Islam and the Challenge of Economic Development. In Altaf Gauhar (Ed.), The Challenge of Islam (pp. 338-349). London: Islamic Council of Europe.

Lucas, R. (1988). On the Mechanisms of Economic Development. Journal of Monetary Economics, $22,3-42$. http://dx.doi.org/10.1016/0304-3932(88)90168-7

Mangeloja, E. (2003). Economic Growth and Religious Production Efficiency. Jyvaskyla, Finland: University of Jyvaskyla, School of Business and Economics.

Mannan, M. (1989). Economic Development and Social Peace in Islam: An analytical study of the process of economic development in the muslim countries of today. London: Ta-Ha Publishers.

Naquib al-Attas, S. M. (2001). Islam: The Concept of Religion and the Foundation of Ethics and Morality. In Altaf Gauhar (Ed.), Prolegomena to the Metaphysics of Islam (2nd ed., pp. 41-90). Kuala Lumpur: International Institute of Islamic Thought and Civilization (ISTAC).

Noland, M. (2005). Religion and Economic Performance. World Development, 33(8), 1215-1232. http://dx.doi.org/10.1016/j.worlddev.2005.03.006

Pesaran, M. H., \& Pesaran, B. (2009). Time Series Econometrics: Using Microfit 5.0. Oxford, UK: Oxford University Press.

Pesaran, M. H., Shin, Y., \& Smith, R. J. (1995). Autoregressive Distributed lag Modelling Approach to Cointegration Analysis. Working Paper No.9514, University of Cambridge, Dept of Economics, Cambridge, UK.

Pesaran, M. H., Shin, Y., \& Smith, R. J. (2001). Bounds Testing Approaches to the Analysis of Level Relationships. Journal of Applied Econometrics, 16, 289-326. http://dx.doi.org/10.1002/jae.616

Pesaran, M., \& Shin, Y. (1999). An Autoregressive Distributed Lag Modelling Approach to Cointegration Analysis. In S. Strom (Ed.), Econometrics and Economic Theory in the 20th Century: The Ragnar Frisch centennial symposium. Cambridge: Cambridge University Press. http://dx.doi.org/10.1017/CCOL521633230.011

Romer, P. (1986). Increasing Returns and Long-run Growth. Journal of Political Economy, 94(5), $1002-1037$. http://dx.doi.org/10.1086/261420

Saleem Qureshi. (1980). Islam and Development: The Zia regime in Pakistan. World Development, 8, $563-575$. http://dx.doi.org/10.1016/0305-750X(80)90041-8

Turkan Ali, Muhammad Abduh, \& Mohd Azmi. (2012). Islamic Banking-Growth Nexus: Evidence from Toda-Yamamoto and bootstrap Granger causality test. Journal of Islamic Finance , 56-66.

Umer Chapra. (1992). Islam and Economic Development. Leicester, UK: International Institute of Economic Thought.

Umer Chapra. (2000). The Future of Economics: An Islamic perspective. Leicester, UK: The Islamic Foundation.

Wan Omar, W. (2012). The Role and Empirical Effects of Islam on Economic Development in Malaysia. Unpublished PhD Thesis. Universiti Utara Malaysia.

Wan Omar, W., Fauzi Hussin, \& Asan Ali, G. (2014). The Trend Analysis of Islamization in Malaysia using Islamization Index as Indicator. Asian Economic and Financial Review, 4(10), 1298-1313.

Wilson, R. (1998). Islam and Malaysia's Economic Development. Journal of Islamic Studies, 9(2), $259-276$. http://dx.doi.org/10.1093/jis/9.2.259 